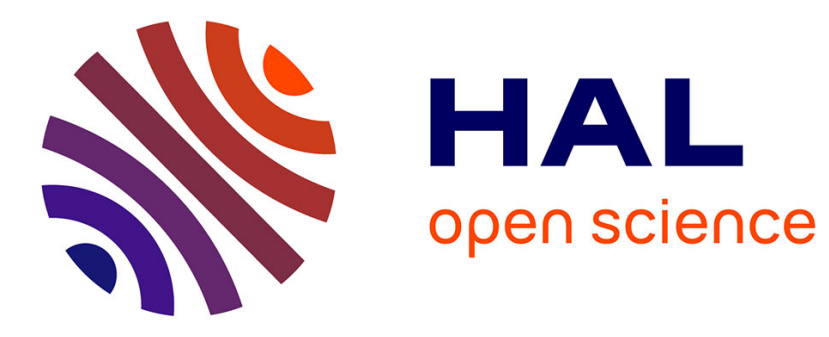

\title{
How is Modern Cinema used as a means of denunciation?
}

Ouedraogo Noufou

\section{To cite this version:}

Ouedraogo Noufou. How is Modern Cinema used as a means of denunciation?. SSRN : Social Science Research Network, 2020. hal-02885363

\section{HAL Id: hal-02885363 \\ https://hal.science/hal-02885363}

Submitted on 30 Jun 2020

HAL is a multi-disciplinary open access archive for the deposit and dissemination of scientific research documents, whether they are published or not. The documents may come from teaching and research institutions in France or abroad, or from public or private research centers.
L'archive ouverte pluridisciplinaire HAL, est destinée au dépôt et à la diffusion de documents scientifiques de niveau recherche, publiés ou non, émanant des établissements d'enseignement et de recherche français ou étrangers, des laboratoires publics ou privés. 


\section{How is Modern Cinema used as a means of denunciation?}

Noufou OUEDRAOGO

Email: o.noufou@ymail.com

Phone: +90 5522035917

Ibn Haldun University 


\section{Introduction}

It seems to be an oxymoron to talk about cinema and denunciation because it opposes artwork and oppression. Thus, it comes down to wondering how artwork can be a means to rebuke authoritarian regimes. In fact, Art is commonly defined as skill, the ability of people to do something expressive, beautiful, and aesthetic (Benjamin Walter, 1936). It is therefore a human activity, the product of this activity, or the idea which is made of it, deliberately addressing the senses, the emotions, the intuitions and the intellect.

Actually, nowadays we cannot talk about cinema without talking about its artistic side. Art becomes thus an integral part of cinema. Since its beginnings, cinema has been intimately linked to magic. Georges Méliès informs us that cinema was born of optical experiments called pre-cinema, where the illusion of movement was in the center of his research (Georges Méliès, 2012). By its hypnotic nature, cinema is the most penetrating language that human beings have conceived. As Henri Langlois said so well, "cinema is an art and art implies artifice". The spectators of cinema are thus immersed in a sensory and dynamic universe where sounds, shapes, materials, vibrant colors and phantasmagoric images evoke real life and create an atmosphere both mysterious and captivating.

However, how can cinema - which is considered somehow as a high art (Bourieu, 1998) - become a means of denunciation? This is what I am going to discuss throughout the following lines of this essay. 


\section{Cinema as a means of denunciation}

If we consider Cinema as an artwork we can say that it is the exaltation of beauty, of aesthetics, but it can also be a very effective means for denouncing political powers and their ideology. According to the English playwright William Shakespeare, artwork is not strong enough to be against political power ${ }^{1}$. However, Cinema can nevertheless be a real means of questioning political forces. Certainly, true artwork liberates the minds of the audience, the public, the society in a word. Its main function is to raise awareness among the public.

In his political comedy film, The Great Dictator (1940), Charlie Chaplin denounces the absurdity of the battles of the First World War through a burlesque satire. He ridicules the authoritarian personality and the megalomania of Hitler (Hynkel) and denounces both the anti-Semitism and the brutality of the Nazi dictatorship through parody. The film goes back to World War I, where a Jewish barber saves the life of an officer. But the plane in which they were embarked crashed after colliding against a tree, and the barber became amnesic and then hospitalized. But he did not know that Jewish are persecuted by Hynkel, the dictator of Tomania. The filmmaker was actually talking about Germany and Adolf Hitler's behaviour during the War and towards the Jewish people.

Moreover, dramatic artwork, as we can consider some films, consists in forging a strange lexicon, which attracts the public in a universe in which it questions the political life. Through the artistic activity, made by the means of stylistic detours and the use of metaphorical forms, the public borrows imaginary bridges to understand the problems of his social and political environment. That is why certain artistic productions, movies specifically, face censorship. Thus, political forces have become increasingly interested in artistic activities. In this perspective, Benjamin Walter talks about the "politicization of art and the aestheticization of politics" in early 1936. In his work entitled "The Work of Art in the Age of Mechanical Reproduction" Walter Benjamin demands a revolutionary art and invites the public to participate critically but also enjoying the works of art.

\footnotetext{
${ }^{1}$ William Shakespeare: Sonnet 65
} 
In cinema, the art of decor and satirical artwork are an integral part of the historical heritage. We cannot talk about cinema without talking about its artistic and criticism aspect. In the field of cinema, the first forms of denunciation began in the early $20^{\text {th }}$ century with David W. Griffith. Already in 1915 Griffith had directed the film entitled The Birth of a Nation, based on the history of the United States of America (USA). In this movie, the director condemns war by denouncing violence in all its forms and praises peace. He condemned the war scenes of the Union against Confederation, the North against the South, and Whites against Black people. Then he had been accused of encouraging racism in the USA. Just after this movie, David W. Griffith directed "Intolerance"' in 1916 where he vehemently decried violence and hypocrisy inspired by religion. Through this film one can learn about the beginning of film industry and its connection with political power.

Similarly, in the film named "Hiroshima my Love", directed in 1959, Alain Resnais keeps a bitter and unforgettable memory of the city devastated by the atomic bomb. Through the long shots scenes, he shows a city reborn from the ashes and life begins again. The director's message is clear: never again an atomic bomb. Still referring to the denunciation through the cinema, we can take the example of "Bronenoset potyomkin" directed by Sergei M. Eisenstein in 1925. Throughout this movie the director shows us wide shots of slaughtered animals. Then all along the following scenes human beings were killed in the same way as the animals. That was a way for Sergei Eisenstein to criticize the horror in war time.

Be it a political, social, religious or cultural issue, cinema of denunciation treats all fields with either humour or gravity. In doing so, filmmakers are inspired by themes such as society, culture and religion. As a matter of fact, the filmmaker Luis Buñuel shows through his film "The Golden Age" directed in 1930 to deal with the insanities and the hypocrisy of modern life, characterized by bourgeois society. It is a surrealist tale of a man and a woman passionately in love with each another, but their attempts to consummate that passion are constantly thwarted by their families, the Church, and the oppressive bourgeois society. Therefore, it is somewhat a manner for him to show the foolish side of modern capitalist society. 
Furthermore, art is the expression of thoughts that seek to understand the world and to make it understood by the public. Thus, the filmmakers, who are indeed considered as artists, are not limited to reality. They add to their works a part of interpretation, they complete their own vision and interpretations of social reality.

Admittedly, artwork is a human specificity whose main purpose is beauty, but it is also a means, not to imitate reality, but to represent it. In his surrealistic film ' $L e$ Fantome de la Liberté", shot in 1974, Luis Buñuel presents unusual and wacky sketches punctuated by scenes of repression. In the midst of Napoleonic wars, Spanish soldiers shout "Damn freedom" before being shot.

Finally, it is not exaggerating to say that cinema is rather a means of asserting one's ideas and exposing them to the spectator who is free to develop a critical thing about it. This is by no means an attempt to manipulation. In comedy movies for instance the political leaders are shown in a worse manner than they are in real life (Aristotle, $\mathrm{V}^{\text {th }}$ B.C.). That is probably why the American filmmaker Woody Allen said that: 'If my film makes one more person feel miserable, I will feel I have done my job , ,2.

\footnotetext{
${ }^{2}$ Woody Allen: Film art an Introduction; Bordwel, David; 1979.
} 


\section{Conclusion}

As it is known, cinema is the $7^{\text {th }}$ art. According to the Italian writer Ricciotto Canudo, as the 7 th art, cinema is a mixture of material and aesthetics. Consequently, it is the most consummate art since it integrates the five artistic elements: language, sound, colour, movement and interactivity. In short, we can say that art is not only a means of imitating reality; but also it allows us to change our view of reality by revealing and recreating it.

In other words, the finality of cinema is the enrichment of culture, knowledge and obviously the denunciation of a system and injustices. Therefore, the cinema can prove to be the best artistic tool to fight against political Powers that the filmmaker wishes to denounce. Accordingly, this impact of a cinema goes far beyond leisure. Artwork can thus allow us to laugh all the time or to magnify the beauty even if the world in which we live is not funny at all! That is why the German philosopher Friedrich Wilhelm Nietzsche saw in art the necessary illusion to support the tragic weight of existence (Beyond Good and Evil, 1892). 


\section{$\underline{\text { References }}$}

Aristotle (1974). Poetics, Gutenberg EBook.

Arnheim, R. (2002). Sanat Olarak Sinema, Öteki Yayınevi.

Bazin, A., (1958). Qu'est-ce que le Cinema? Éditions du Cerf, Paris.

Bazin, A., (1966). Çağdaş Sinemanın Sorunları - Bilgi Yayinları/Istanbul.

Benayoun, R., (1968). The King is Naked, The New Wave, Peter Graham edition, Cinema World Series, Doubleday, New York.

Benjamin, W., (1936). The Work of Art in the Age of Mechanical Reproduction. Cambridge University Press.

Bernstein, S., (1994). Film production, Focal Press, Oxford.

Block, A. B., (2008). The visual story: Creating the Visual Structure of Film, TV and Digital Media, Focal Press, Burlington.

Edward Sparshott, E., F., (1971). Basic Film Aesthetics; University of Illinois Press, (1971)

Eisenstein, S., \& Leyda, J., (1949). Film Form, essays, Harcourt editions, New York.

Houdini, H., , (2011). A Magician Among the Spirits, Cambridge University Press.

Langois, H., (1992). Méliès: un homme d'illusions, Centre national de la photographie, Paris.

Malraux, A., (1939). Psychologie du cinéma, essai, Revue Verve, Paris.

McGowan, T., (2007). The Real Gaze - Film Theory After Lacan, State University of New York Press.

Méliès, G., (2012). La Vie et l'Euvre d'un pionnier du cinéma, Les Éditions du Sonneur, coll. Paris.

Mulvey, L. (2012). Saniyede 24 Kare Ölüm - Duraganlık ve Hareketli Görüntü; Doruk Yayımcılık.

Peter Wollen, P., (1969) Signs and Meaning in the Cinema, BFI Silver edition.

Platon, (1972). La République, Livre IV, (by Robert Bacou), Edition Les Belles Lettres, Paris.

Tarkovsky, A., (1984). Sculpting in Time; University of Texas Press.

Wheeler, P., (2005). Practical Cinematography, Focal Press, Oxford.

Wölfflin, H., (1950) Principles of art history, Dover Publications, Inc. New York. 